\title{
Brain-Derived Neurotrophic Factor and Glial Cell Line-Derived Neurotrophic Factor Are Required Simultaneously for Survival of Dopaminergic Primary Sensory Neurons In Vivo
}

\author{
Jeffery T. Erickson, Teresa A. Brosenitsch, and David M. Katz \\ Department of Neurosciences, Case Western Reserve University School of Medicine, Cleveland, Ohio 44106
}

Null mutations affecting members of the transforming growth factor- $\beta$ and neurotrophin families result in overlapping patterns of neuronal cell death. This is particularly striking in the cranial sensory nodose-petrosal ganglion complex (NPG), in which loss of either glial cell line-derived neurotrophic factor (GDNF), brain-derived neurotrophic factor (BDNF), neurotrophin-3 (NT3 ), or neurotrophin-4 (NT-4) results in a 30-50\% reduction in neuronal survival. It is unknown, however, whether GDNF and any single neurotrophin support survival of the same cells, and if so, whether they are required simultaneously or sequentially during development. To approach these issues we defined survival requirements of nodose and petrosal neurons for GDNF in vitro and in bdnf, gdnf, and bdnf/gdnf null mutant mice, as well as the distribution of GDNF in NPG target tissues. Our analyses focused on the total population of ganglion cells as well as the subset of NPG neurons that are dopaminergic.

Glial cell line-derived neurotrophic factor (GDNF) and the related proteins neurturin, persephin, and artemin, comprise a subgroup of the transforming growth factor- $\beta$ superfamily of growth and differentiation factors. The GDNF family members signal through a receptor complex consisting of a ligand-specific glycosyl-phosphatidylinositol-linked binding molecule (GFR $\alpha)$ and the membrane-spanning RET (rearranged during transfection) receptor tyrosine kinase (Rosenthal, 1999; Baloh et al., 2000). GDNF supports survival of a variety of peripheral and central neurons in vitro, including midbrain dopaminergic, spinal motor, sympathetic, parasympathetic, peripheral sensory, and enteric neurons (for review, see Unsicker et al., 1998). However, analysis of GDNF or GFR $\alpha 1$ knock-out mice has revealed that a more restricted subset of neurons requires GDNF for survival in vivo (Moore et al., 1996; Pichel et al., 1996; Sanchez et al., 1996; Cacalano et al., 1998).

One of the most severely affected neuronal populations in GDNF knock-out mice is the nodose-petrosal ganglion complex (NPG) of primary cranial sensory neurons, in which $40 \%$ of cells die by birth (Moore et al., 1996). Interestingly, targeted disruption of the genes encoding brain-derived neurotrophic factor

\footnotetext{
Received Sept. 6, 2000; revised Oct. 23, 2000; accepted Nov. 2, 2000.

This work was supported by Public Health Service grants (National Heart, Lung, and Blood Institute) to D.M.K. We thank Drs. Mariano Barbacid and William Snider for providing GDNF knock-out mice, Regeneron Pharmaceuticals for providing BDNF knock-out mice and BDNF protein, and Roseann Brady and Feiwen $\mathrm{Yu}$ for expert technical assistance.

Correspondence should be addressed to Dr. David M. Katz, Department of Neurosciences, Case Western Reserve University School of Medicine, 10900 Euclid Avenue, Cleveland, OH 44106. E-mail: dmk4@po.cwru.edu.

Copyright (C) 2001 Society for Neuroscience 0270-6474/01/210581-09\$15.00/0
}

Neuron losses in bdnf/gdnf double mutants are not additive of the losses in single bdnf or gdnf null mutants, indicating that many cells, including dopaminergic neurons, require both GDNF and BDNF for survival in vivo. Moreover, both factors are required during the same period of development, between embryonic day (E) 15.5 and E17.5. In addition, GDNF, like BDNF is expressed in target tissues at the time of initial target innervation and coincident with GDNF dependence of the innervating neurons. Together, these findings demonstrate that both GDNF and BDNF can act as target-derived trophic factors and are required simultaneously for survival of some primary sensory neurons.

Key words: GDNF; BDNF; primary sensory neurons; growth factors; neurotrophins; knock-out mice; nodose ganglion; petrosal ganglion; carotid body
(BDNF) (Ernfors et al., 1994b; Jones et al., 1994; Conover et al., 1995; Liu et al., 1995; Erickson et al., 1996), neurotrophin-3 (NT-3) (Ernfors et al., 1994a; Farinas et al., 1994), or neurotrophin-4 (NT-4) (Conover et al., 1995; Liu et al., 1995; Erickson et al., 1996) also leads to loss of $30-50 \%$ of NPG neurons, suggesting that some neurons require both GDNF and a neurotrophin for survival in vivo. However, it is unknown whether GDNF and the neurotrophins act simultaneously or sequentially. Moreover, the relationship between GDNF dependence of NPG neurons and GDNF expression in target tissues has not been defined. We showed previously, for example, that BDNF is expressed transiently in NPG targets, such as the carotid body and cardiac outflow tract, coincident with the onset of sensory innervation, supporting a role for BDNF as a targetderived survival factor (Brady et al., 1999). Some NPG targets, including the carotid body, have also been reported to express GDNF mRNA (Nosrat et al., 1996), raising the possibility that survival of some NPG neurons is supported by two target-derived factors, BDNF and GDNF.

To approach these issues we defined trophic requirements of NPG neurons for BDNF and GDNF by comparing ganglion cell numbers in wild-type mice and knock-out mice lacking either BDNF or GDNF, or both BDNF and GDNF. In addition, to examine the relationship between GDNF dependence and target innervation, we analyzed survival requirements of different ganglion cell subpopulations, including dopaminergic (DA) neurons in the PG that selectively innervate the carotid body, as well as the distribution of GDNF protein in target tissues. 


\section{MATERIALS AND METHODS}

\section{Animals}

Embryos were obtained from timed pregnant rats (Sprague Dawley; Zivic-Miller, Zelionople, PA) and from crosses of heterozygous or double heterozygous mice carrying single null alleles for $b d n f$ (Conover et al., 1995), gdnf (Sanchez et al., 1996), or both bdnf and gdnf. To assign gestational ages, the day after mating (determined by the presence of a vaginal plug) was designated embryonic day 0.5 (E0.5). Mouse embryos from $b d n f$ or $g d n f$ single heterozygous crosses were collected on E13.5, E14.5, and E15.5, and embryos from both single and double heterozygous crosses were obtained on E17.5. Developmental stages were confirmed by crown-rump length measurements and assessment of morphological features (Theiler, 1972). Newborn animals from $b d n f$ and $g d n f$ single heterozygous crosses as well as $b d n f / g d n f$ double heterozygous crosses were obtained on the day of birth. All mice were genotyped by PCR amplification of isolated tail DNA, using $b d n f$ - and $g d n f$-specific primer pairs.

\section{Cell culture}

\section{Explant cultures}

Pregnant rats were killed by exposure to carbon dioxide. The uterine horns were removed, placed into PBS, $\mathrm{pH} 7.4$, and the fetuses (E16.5) were excised. Tissue blocks containing the NPG were transferred to 0.1 M PBS containing $10 \%$ glucose; the petrosal ganglia were then removed and placed individually in drops of Matrigel basement membrane matrix (Collaborative Research, Bedford, MA) in plastic tissue culture plates and incubated in Leibovitz's medium containing 10\% NuSerum (Collaborative Research), $5 \%$ heat-inactivated rat serum, fresh vitamin mixture (Mains and Patterson, 1973), penicillin (50 IU $/ \mathrm{ml})$, and streptomycin (50 $\mu \mathrm{g} / \mathrm{ml})$. Explant cultures were grown for $3 \mathrm{~d}$ in an incubator $\left(37^{\circ} \mathrm{C}, 5 \%\right.$ $\mathrm{CO}_{2}$ ) in the absence or presence of different concentrations of GDNF (catalog \#A52450H; concentration range, 0.1-500 ng/ml; Biodesign International, Saco, ME), then fixed in $4 \%$ paraformaldehyde (in $0.1 \mathrm{M}$ PBS, $\mathrm{pH}$ 7.4) overnight at $4^{\circ} \mathrm{C}$. The ganglia were then infiltrated with $30 \%$ sucrose in PBS, frozen in TissueTek embedding medium (Baxter Scientific, McGraw Park, IL), cut $(10 \mu \mathrm{m})$ in a cryostat, thawed onto gelatin-coated glass slides, and processed for immunohistochemical staining as described below.

\section{Dissociate cultures}

Fetal (E16.5) rat PG were dissected into 0.1 m PBS containing $10 \%$ glucose, transferred briefly to Dulbecco's $\mathrm{Ca}^{2+}$ - and $\mathrm{Mg}^{2+}$-free PBS, then digested enzymatically in Dispase (Collaborative Research; diluted 1:1 in PBS) for $30 \mathrm{~min}$ at $37^{\circ} \mathrm{C}$. The ganglia were triturated in Leibovitz's medium (see above), and cells were plated at a density of three PG per well onto glass coverslips coated with polylysine $(0.1 \mathrm{mg} / \mathrm{ml})$ and laminin $(0.3 \mu \mathrm{g} / \mathrm{ml})$. Cultures were placed in an incubator $\left(37^{\circ} \mathrm{C}, 5 \% \mathrm{CO}_{2}\right)$ and grown for $3 \mathrm{~d}$ in Leibovitz's medium in the absence or presence of GDNF alone (Biodesign International), BDNF alone (Regeneron Pharmaceuticals, Tarrytown, NY), or both GDNF and BDNF simultaneously. Two separate experiments using either subsaturating $(5 \mathrm{ng} / \mathrm{ml})$ or saturating $(100 \mathrm{ng} / \mathrm{ml})$ concentrations of GDNF and BDNF were performed. Cultures subsequently were fixed for $20 \mathrm{~min}$ in $4 \%$ paraformaldehyde, rinsed thoroughly in $0.1 \mathrm{M}$ PBS, then processed for immunohistochemical staining as described below.

\section{Immunohistochemical procedures}

\section{Cell cultures}

Double immunostaining was performed as previously described (Hertzberg et al., 1994; Erickson et al., 1996) using polyclonal antityrosine hydroxylase (TH) (1:200; Pel-Freez, Rogers, AR), monoclonal anti-neurofilament protein $\left(\mathrm{NF}_{68,160}\right)$ (1:100; Sigma, St. Louis, MO), goat anti-rabbit IgG-FITC (1:200; Boehringer Mannheim, Indianapolis, IN), and goat anti-mouse IgG-rhodamine (1:200; Cappel Research Products, Organon Teknika, Durham, NC) antibodies.

\section{Intact ganglia}

Tissue blocks containing the NPG were dissected from fetal mice and immersion-fixed for $2-4 \mathrm{hr}$ in $2 \%$ paraformaldehyde containing $0.2 \%$ $\rho$-benzoquinone in 0.07 M PBS (Conner et al., 1997) or in $2 \%$ paraformaldehyde in $0.1 \mathrm{M}$ PIPES buffer, $\mathrm{pH}$ 7.4. Newborn animals were deeply anesthetized with sodium pentobarbital (6 gm/ kg, i.p.) and perfused through the heart with $4 \%$ paraformaldehyde in $0.1 \mathrm{~m}$ PBS. The head of the animal was removed, hemisected along the midline, and post-fixed overnight. All tissues were infiltrated with $30 \%$ sucrose for $24-48 \mathrm{hr}$, placed in a $1: 1$ mixture of $30 \%$ sucrose and TissueTek embedding medium for $24 \mathrm{hr}$, embedded and frozen in TissueTek, and stored at $-80^{\circ} \mathrm{C}$ until use. Before immunostaining, frozen parasagittal sections $(10$ $\mu \mathrm{m}$ ) were cut and thaw-mounted onto microscope slides (Superfrost Plus; Fisher Scientific, Pittsburgh, PA). Tyrosine hydroxylase immunostaining was performed as described previously (Erickson et al., 1996).

To detect endogenous GDNF, sections containing the carotid body were hydrated in $0.1 \mathrm{M}$ PBS, quenched with $0.5 \% \mathrm{H}_{2} \mathrm{O}_{2}$ in methanol for 15 min, rinsed in PBS, soaked for $1 \mathrm{hr}$ in dilution buffer (PBS containing $10 \%$ donkey serum and $0.3 \%$ Triton X-100), blocked with avidin (15 min; Vector Laboratories, Burlingame, CA), rinsed with PBS, blocked with biotin (15 min; Vector Laboratories), rinsed again with PBS, placed in dilution buffer (15 $\mathrm{min})$, then incubated overnight at room temperature with a goat anti-GDNF polyclonal antibody (catalog \#AF-212-NA; 0.125 $\mu \mathrm{g} / \mathrm{ml}$ diluted in $0.1 \mathrm{M}$ PBS with $10 \%$ donkey serum; R \& D Systems, Minneapolis, MN). Sections were then rinsed thoroughly with PBS, incubated for $30 \mathrm{~min}$ with biotinylated donkey anti-goat IgG (catalog \#705-066-147, diluted 1:1000 in 0.1 M PBS with 10\% donkey serum; Jackson ImmunoResearch, West Grove, PA), rinsed repeatedly with PBS, reacted with ABC Elite reagent (30 min, 1:100 in 0.5 M NaCl-PBS; Vector Laboratories), rinsed in NaCl-PBS (10 min) followed by TNT $(0.1 \mathrm{~m}$ Tris- $\mathrm{HCl}, 0.15 \mathrm{M} \mathrm{NaCl}$, and $0.5 \%$ Tween $20 ; 2 \times 10 \mathrm{~min})$, and TNB $(0.1 \mathrm{~m}$ Tris-HCl, $0.15 \mathrm{M} \mathrm{NaCl}$, and $0.5 \%$ blocking reagent from TSA kit, 10 min; NEN Life Science Products, Boston, MA), then incubated in biotinyl tyramide solution ( $5 \mathrm{~min} ; 1$ :50; TSA kit). After tyramide amplification, sections were rinsed in TNT $(3 \times 10 \mathrm{~min})$, soaked in TNB (10 min), incubated in ABC Elite reagent (30 min, 1:50 in $0.5 \mathrm{M} \mathrm{NaCl}-$ PBS), washed sequentially with $0.5 \mathrm{M} \mathrm{NaCl}$-PBS followed by PBS $(2 \times 10$

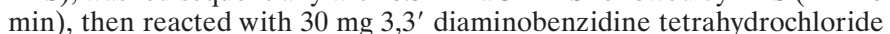
diluted in $100 \mathrm{ml}$ PBS containing $400 \mu \mathrm{l}$ of $0.8 \% \mathrm{NiCl}_{2}$ and $25 \mu \mathrm{l}$ of $30 \%$ $\mathrm{H}_{2} \mathrm{O}_{2}$. Finally, sections were rinsed in distilled water, then coverslipped with glycerol gel.

RET immunostaining was performed using a biotinylated goat antiRET antibody (catalog \#BAF-482, $0.625 \mu \mathrm{g} / \mathrm{ml}$; R \& D Systems). The procedure used was identical to that described above for GDNF, except that a secondary antibody was not required. Double immunostaining for RET and TH was performed using TSA amplification of RET, as described above, followed sequentially by TH immunostaining (Erickson et al., 1996), using an FITC-conjugated donkey anti-rabbit antibody (catalog \#711-095-152; 1:200; Jackson ImmunoResearch).

For both GDNF and RET, negative control sections were processed as described above in the absence of the primary antibody.

\section{Cell counts}

\section{Explant cell cultures}

The number of TH- and NF-immunoreactive cell profiles was obtained by counting all stained cells containing a nucleus in every other section through each explant ganglion. Video images of sections were captured, nuclear diameters were measured in a subset of neurons (NIH Image, version 1.55), and these data were used to estimate total neuron number from the profile counts (Abercrombie, 1946).

\section{Dissociate cell cultures}

TH- and NF-immunoreactive cells were counted from three longitudinal strips through the center of each dissociate culture $(\sim 10 \%$ of the total area), and the mean of these counts was used to estimate both the total number of neurons and the number of DA neurons per well.

\section{Intact ganglia}

Total cell counts. Frozen sections from newborn wild-type, bdnf ${ }^{-/-}$, $g d n f^{-1-}$ and $b d n f^{-1-} g d n f^{-1-}$ mice were stained with $0.1 \%$ cresyl violet acetate and analyzed to estimate total neuron number, as described previously (Erickson et al., 1996). Briefly, all sections with the NPG were identified and, beginning from a randomly selected section, every sixth section was selected for analysis. The cross-sectional area occupied by neurons was measured separately for the nodose (NG) and petrosal (PG) ganglion (NIH Image, version 1.55), and the volume of each ganglion occupied by neurons $\left(\mu \mathrm{m}^{3} \times 10^{6}\right)$ was estimated from the area measurements, section thickness, and the total number of sections containing each ganglion. Total neuronal profile number within each ganglion was then estimated by randomly selecting a section, counting the number of neuronal nuclei within a measured area of the section, then calculating neuronal density [number of nuclei/(measured area $\times$ section thick- 

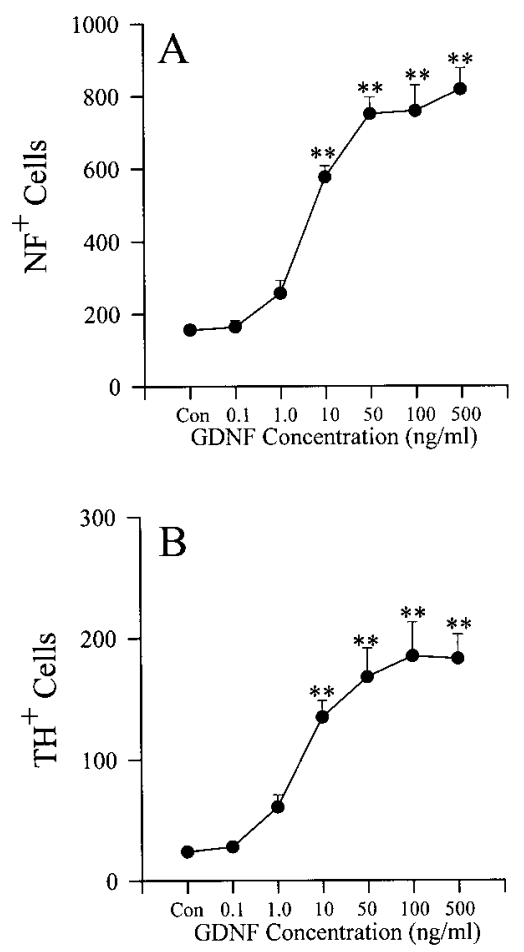

Figure 1. GDNF supports survival of PG sensory neurons in culture, including the subset that normally expresses dopaminergic traits in vivo. E16.5 rat PG explants were grown for $3 \mathrm{~d}$ in the absence or presence of different concentrations of GDNF (range, $0.1-500 \mathrm{ng} / \mathrm{ml}$ ) and then processed for neurofilament (NF) and $\mathrm{TH}$ immunostaining. In the presence of saturating concentrations $(50 \mathrm{ng} / \mathrm{ml})$ of GDNF, the number of total $\left(N F^{+}\right)$and DA $\left(T H^{+}\right)$neurons increased 4.8-fold $(A)$ and 7-fold $(B)$, respectively, compared with untreated controls (Con). The percentage of $\mathrm{TH}^{+}$cells remained constant at $22-24 \%$ at all GDNF concentrations, indicating that the dose-dependent increases in $\mathrm{TH}^{+}$cell number were attributable to increased survival, rather than upregulation of TH expression from previously undetectable levels. Bars represent means \pm SEM of at least five cultures per group. $* p<0.001$.

ness)]. This procedure was repeated in approximately every sixth section through the ganglion, and the mean of these measurements was multiplied by the volume of the ganglion occupied by neurons. No correction factor was applied.

TH cell counts. All TH-immunostained neuronal profiles with a nucleus in the plane of section were counted separately for the NG and PG in every sixth section. No correction factor was applied.

\section{Plethysmography}

Breathing frequency was measured in 6- to 12-hr-old wild-type and gdnf ${ }^{-1-}$ mice using previously described plethysmographic methods (Mortola and Noworaj, 1983; Mortola, 1984). Briefly, individual unanesthetized animals were placed in a plethysmographic chamber $(\sim 20 \mathrm{ml}$ volume), with the head of the animal emerging through a nonrestricting but airtight latex/parafilm seal. A two-sidearm pneumotachograph (Mortola, 1984) was attached to the test chamber, with the sidearms connected in turn to two leads of a differential pressure transducer (model \#DP103; Validyne Engineering Corporation, Northridge, CA) to measure airflow in and out of the chamber caused by breathing movements. The airflow signal was used to determine respiratory frequency during periods of quiet resting ventilation as well as to detect apneas (defined as periods in which breathing ceased for $\geq 2 \mathrm{sec}$ ). Temperature in the body plethysmograph was monitored continuously and kept constant within the thermoneutral range for newborn mice $\left(32-34^{\circ} \mathrm{C}\right)$. The airflow signal was captured, digitized, and stored on disk (Axotape; Axon Instruments, Foster City, CA) for subsequent computer analysis using commercially available software (Acquis1; Bio-Logic Science Instruments, Claix, France). The animal was allowed to acclimate to the chamber for $5 \mathrm{~min}$ before recording ventilation continuously for an additional $5 \mathrm{~min}$. Each record was analyzed to determine breathing frequency during quiet resting ventilation. Portions of the record that were corrupted by movement artifact, as well as periods of apnea, were excluded from the frequency analysis. In addition, the number of apneas and the percentage of recording time spent in apnea were measured.

\section{Statistical analyses}

Data were analyzed by Student's $t$ test or by ANOVA followed by the least significant difference multiple comparison procedure (Statistica; StatSoft, Tulsa, OK). A $p$ value of $<0.05$ was considered statistically significant.

\section{RESULTS}

\section{Survival in vitro}

Initial experiments, using explant cultures of the E16.5 rat PG, demonstrated that the total number of neurons $\left(\mathrm{NF}^{+}\right.$; Fig. $\left.1 A\right)$ and the number of TH-immunoreactive DA neurons $\left(\mathrm{TH}^{+}\right.$; Fig. $1 B$ ) increased 4.8-fold and 7-fold, respectively, in the presence of a saturating concentration of GDNF $(50 \mathrm{ng} / \mathrm{ml})$ compared with controls (Con). The percentage of $\mathrm{TH}^{+}$cells remained constant (22-24\%) at all GDNF concentrations, indicating that the increase in $\mathrm{TH}^{+}$cell number observed in the presence of GDNF was attributable to increased survival, rather than upregulation of TH expression from previously undetectable levels. In confirmation of previous results in chick (Buj-Bello et al., 1995; Trupp et al., 1995) and mouse (Henderson et al., 1994), GDNF also supported survival of dissociate rat NG neurons; at $50 \mathrm{ng} / \mathrm{ml}$, GDNF

\begin{tabular}{|c|c|c|c|c|}
\hline Genotype & Total profile & Change & $\mathrm{TH}^{+}$profile & Change \\
\hline$(b d n f / g d n f)$ & Number $(n)$ & $(\%)$ & Number $(n)$ & $(\%)$ \\
\hline A. $(+/+) /(+/+)$ & $3816 \pm 369(12)$ & 0 & E. $253 \pm 12(23)$ & 0 \\
\hline B. $(+/+) /(-/-)$ & $2329 \pm 260(10)^{a, d, e}$ & -39 & F. $147 \pm 12(15)^{a, b, c}$ & -42 \\
\hline C. $(-/-) /(+/+)$ & $1882 \pm 150(5)^{a, d}$ & -51 & G. $106 \pm 12(13)^{a, d}$ & -58 \\
\hline D. $(-/-) /(-/-)$ & $1435 \pm 180(5)^{a}$ & -62 & H. $97 \pm 14(6)^{a}$ & -62 \\
\hline
\end{tabular}

Profile counts are shown as means \pm SEM. Percent change is relative to wild-type.

${ }^{a}$ Differs from $b d n f^{+/+} g d n f^{+/+}$(wild-type).

${ }^{b}$ Differs from $b d n f^{-/-} g d n f^{+/+}($BDNF knock-out; $p<0.05)$.

${ }^{c}$ Differs from $b d n f^{-/-} g d n f^{-/-}$(BDNF/GDNF double knock-out; $\left.p<0.05\right)$.

${ }^{d}$ Not different from $b d n f^{-/-} g d n f^{-/-}$(BDNF/GDNF double knock-out).

${ }^{e}$ Not different from $b d n f^{-/-} g d n f^{+/+}$(BDNF knock-out). 

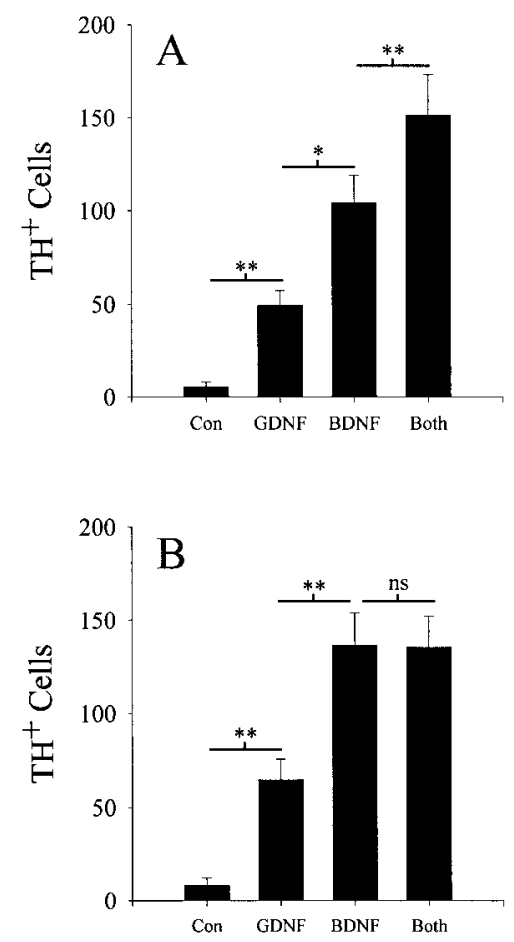

Figure 2. Combined treatment with GDNF and BDNF produces an additive increase in dopaminergic PG neuron survival in vitro at subsaturating, but not saturating, concentrations of each factor. E16.5 rat PG dissociate cultures were grown for $3 \mathrm{~d}$ in the absence (Con) or presence of GDNF alone $(G D N F), \mathrm{BDNF}$ alone $(B D N F)$, or both GDNF and BDNF (Both) and then immunostained for TH. At $5 \mathrm{ng} / \mathrm{ml}$ of each factor $(A), \mathrm{TH}^{+}$neuron survival was increased 9-, 19-, and 28-fold in the presence of GDNF, BDNF, and GDNF plus BDNF, respectively, compared with control cultures. In contrast, at $100 \mathrm{ng} / \mathrm{ml}$ of each factor $(B)$, there was no additive effect on survival of GDNF plus BDNF above the level seen in the presence of BDNF alone. Bars represent means \pm SEM of at least six cultures per group. $* p<0.05$; * $p<0.01 ; n s$, not significant.

increased total and $\mathrm{TH}^{+}$neuron number by 3.4-fold and 6.9-fold, respectively, compared with untreated controls (data not shown).

To determine whether GDNF supports survival of the same or different neurons supported by BDNF (Erickson et al., 1996; Brady et al., 1999), we compared the effects of the two factors alone or in combination on $\mathrm{PG} \mathrm{TH}^{+}$neuron survival in dissociate cell culture. At subsaturating concentrations of $5 \mathrm{ng} / \mathrm{ml}$, the combined effect of GDNF plus BDNF was additive of the effect of each factor alone (Fig. $2 A$ ). However, at saturating concentrations for both BDNF and GDNF (100 ng/ml), the combined effect of GDNF plus BDNF was no greater than the effect of BDNF alone (Fig. 2B). These data indicate that the population of neurons supported by GDNF alone is a subset of the population supported by BDNF alone and suggest that some cells can be supported by subthreshold levels of both factors acting in concert.
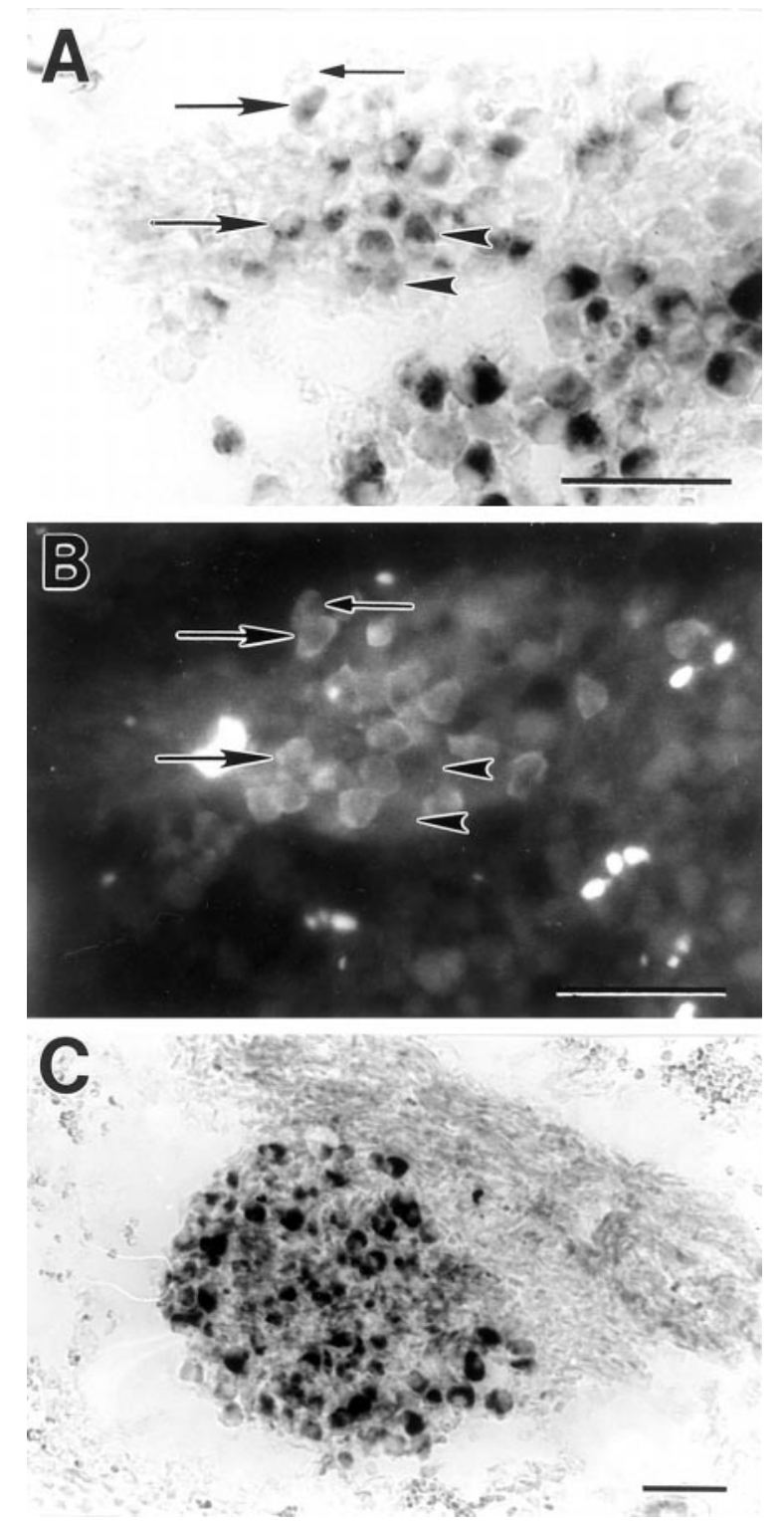

Figure 3. Many dopaminergic neurons in the mouse PG coexpress RET, the signaling component of the GDNF receptor. Photomicrographs show RET $(A)$ and TH $(B)$ immunostaining in the same tissue section through the PG of a wild-type E17.5 mouse embryo. Many TH-positive neurons are also RET-immunoreactive (large arrows). However, TH-positive/ RET-negative (small arrows) and RET-positive/TH-negative (arrowheads) neurons were also observed. Approximately $43 \%$ of all dopaminergic neurons in the PG express RET $(n=5)$. RET immunoreactivity was also prominent in the E17.5 NG $(C)$. Scale bar, $50 \mu \mathrm{m}$.

Table 2. Counts of total and $\mathrm{TH}^{+}$neuronal profiles in the nodose ganglion from newborn wild-type $(+/+/+/+)$ and $g d n f$ homozygous $(+/+/-/-)$ mice

\begin{tabular}{|c|c|c|c|c|}
\hline Genotype & Total profile & Change & $\mathrm{TH}^{+}$ & Change \\
\hline$(b d n f / g d n f)$ & Number $(n)$ & $(\%)$ & Number $(n)$ & $(\%)$ \\
\hline$(+/+) /(+/+)$ & $8336 \pm 758(12)$ & 0 & $303 \pm 20(23)$ & 0 \\
\hline$(+/+) /(-/-)$ & $8264 \pm 731(10), \mathrm{NS}$ & -1 & $296 \pm 23(15), \mathrm{NS}$ & -2 \\
\hline
\end{tabular}

Profile counts are shown as means \pm SEM. Percent change is relative to wild-type.

NS, Not different from $b d n f^{+/+} g d n f^{+/+}$(wild-type). 
Table 3. Counts of $\mathrm{TH}^{+}$neurons in the petrosal ganglion that coexpress RET from newborn wild-type $(+/+/+/+)$, gdnf homozygous $(+/+/-/-)$, bdnf homozygous $(-/-/+/+)$, and bdnf/gdnf double homozygous $(-/-/-/$ -) mice

\begin{tabular}{lcc}
\multicolumn{1}{l}{ Genotype } & \multicolumn{1}{c}{ Total profile } & \\
$($ bdnf/gdnf $)$ & Number $(n)$ & $(\%)$ \\
\hline A. $(+/+) /(+/+)$ & $133 \pm 12(5)$ & 0 \\
B. $(+/+) /(-/-)$ & $33 \pm 6(5)^{a, b, c}$ & -75 \\
C. $(-/-) /(+/+)$ & $47 \pm 5(4)^{a, b}$ & -65 \\
D. $(-/-) /(-/-)$ & $2 \pm 1(5)^{a}$ & -98
\end{tabular}

$\overline{\text { Profile counts are shown as means } \pm \text { SEM. Percent change is relative to wild-type. }}$ ${ }^{a}$ Differs from $b d n f^{+/+} g d n f^{+/+}$(wild-type).

${ }^{b}$ Differs from $b d n f^{-/-} g d n f^{-/-}$(BDNF/GDNF double knock-out).

${ }^{c}$ Not different from $b d n f^{-/-} g d n f^{+/+}$(BDNF knock-out).

\section{Analysis of bdnf, gdnf, and bdnf/gdnf null mutants}

The fact that GDNF supports survival of both NG and PG neurons in vitro is consistent with the finding that many NPG sensory neurons are lost in gdnf null mutant mice (Moore et al., 1996). However, NG and PG neurons innervate different peripheral targets, and it is unknown whether the cell loss reported for the NPG complex as a whole is restricted to one or the other, or both, of these populations. To address this issue we compared cell number separately in the NG and PG neuron pools of newborn wild-type and gdnf null mutant mice, including the DA subpopulation in each ganglion. We found that loss of both GDNF alleles led to a $39 \%$ reduction in total $\mathrm{PG}$ neuron number, and a comparable $42 \%$ decrease in the number of $\mathrm{TH}^{+} \mathrm{DA}$ neurons, compared with wild-type controls (Table 1 , compare $A, B$ to $E, F$ ). The magnitude of the DA cell loss correlates well with the fact that $\sim 43 \%$ of $\mathrm{TH}^{+}$PG neurons in wild-type animals express the GDNF receptor RET (Fig. $3 A, B$ ), indicating that for this popu- lation of cells, RET expression is a reliable marker of GDNF dependence. In contrast, we found no difference in either total or $\mathrm{TH}^{+}$cell number in the NG of newborn wild-type and $g d n f^{-/-}$ mice (Table 2). Thus, despite the fact that many NG neurons are supported by GDNF in vitro and express RET in vivo (Fig. $3 C$ ), they do not require GDNF for survival in vivo.

We reported previously that $\sim 50 \%$ of neurons in the $\mathrm{NPG}$, including $58 \%$ of the DA population, are depleted in newborn mice lacking BDNF (Erickson et al., 1996; see also ElShamy and Ernsfors, 1997). To determine whether BDNF and GDNF support survival of the same or different subsets of PG neurons, we also compared ganglion cell numbers in newborn $b d n f^{-1-}$ and $b d n f^{-1-} g d n f^{-1-}$ mice (Table $1 C, D, G, H$ ). Disruption of both $b d n f$ alleles resulted in a $51 \%$ deficit in total ganglion cell number compared with wild-type controls (Table 1C), similar to our previous findings (Erickson et al., 1996). Disruption of both bdnf and both $g d n f$ alleles (Table $1 D$ ) resulted in a $62 \%$ reduction in PG neuron number that was not significantly different from the loss resulting from disruption of either both $b d n f(p=0.462)$ or both $\operatorname{gdnf}(p=0.100)$ alleles alone. Analysis of the DA subpopulation of PG neurons revealed a $58 \%$ deficit in $b d n f^{-/-}$mice, compared with wild-type controls (Table $1 G$ ) that was not significantly different from the loss observed in $b d n f^{-/-} g d n f^{-/-}$ animals $(-62 \%$; Table $1 H ; p=0.699)$. Taken together, our data demonstrate that those PG neurons that depend on GDNF alone for survival in vivo constitute a subset of neurons that are supported by BDNF alone, consistent with our findings in culture (Fig. 2). Thus, the $39 \%$ of all PG neurons and the $42 \%$ of DA PG neurons that are lost after knock-out of only GDNF are a subset of the neurons that are lost after knock-out of BDNF alone, and therefore require both GDNF and BDNF for survival in vivo.

To define the role of GDNF in survival of DA PG neurons in more detail, we analyzed the subpopulation of DA neurons that
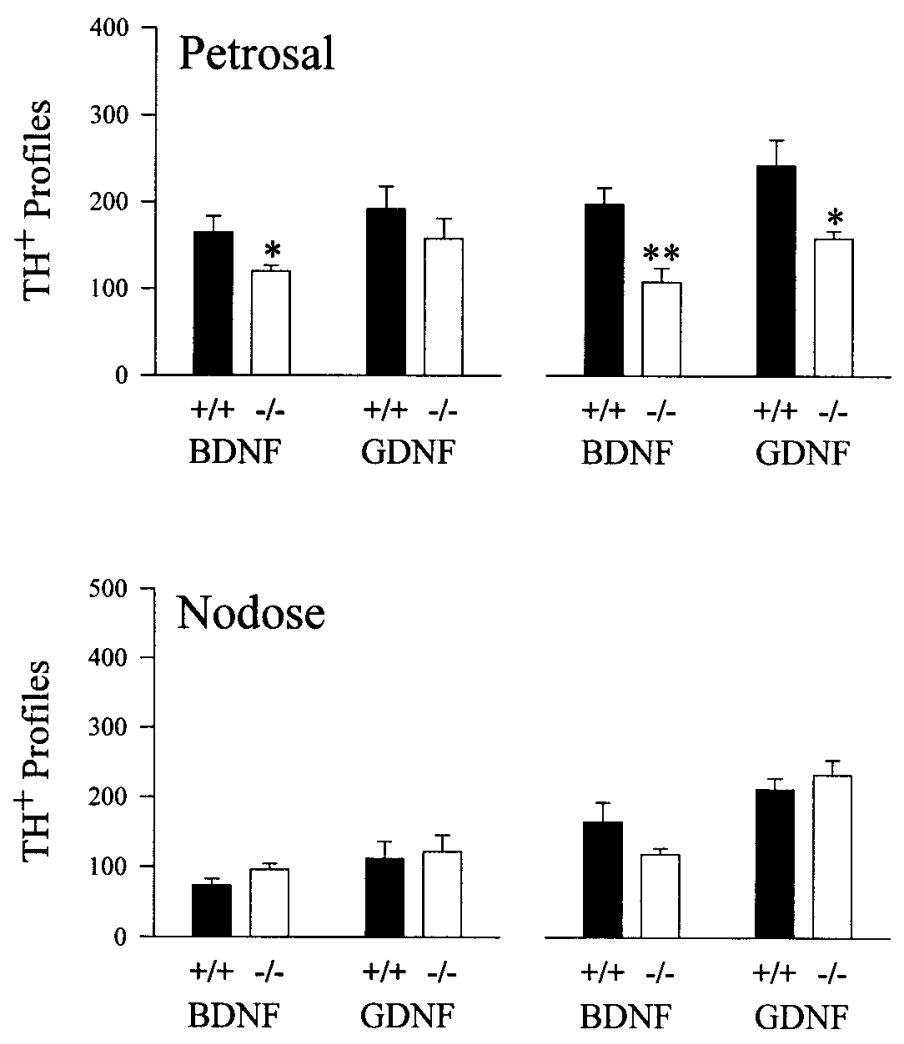

E14.5

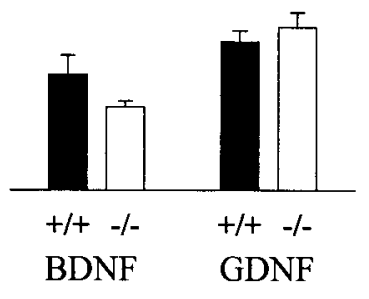

E15.5

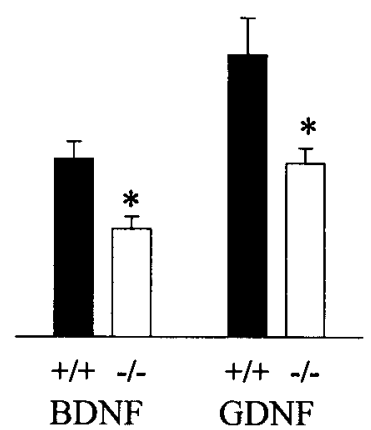

Figure 4. The timing of dopaminergic cell losses in the PG from $b d n f^{-I-}$ and $g d n f^{-1-}$ mutant mice overlap. The number of dopaminergic $\left(\mathrm{TH}^{+}\right)$neurons in the $\mathrm{PG}$ (top panel) and NG (bottom panel) from wild-type $(+/+$, filled bars $)$ and homozygous $(-/-$, open bars $)$ mice on E14.5, E15.5, and E17.5 were counted after TH immunostaining. At each developmental age, $\mathrm{TH}^{+}$cell numbers in wild-type and knock-out animals were compared separately within each genotype using Student's $t$ test $(\alpha=0.05)$. Significant differences between wild-type and homozygotes were first detected in the PG on E14.5 for $b d n f^{-1-}$ mice and on E15.5 for $g d n f^{-1-}$ animals (top panel), whereas no differences in $\mathrm{TH}^{+}$cell number were detected in the NG between wild-type and $g d n f^{-/-}$mutant mice at any of the developmental ages tested (bottom panel). Data are presented as means \pm SEM. Sample sizes ranged from five to eight. ${ }^{*} p<0.05 ;{ }^{*} p<0.01$. 


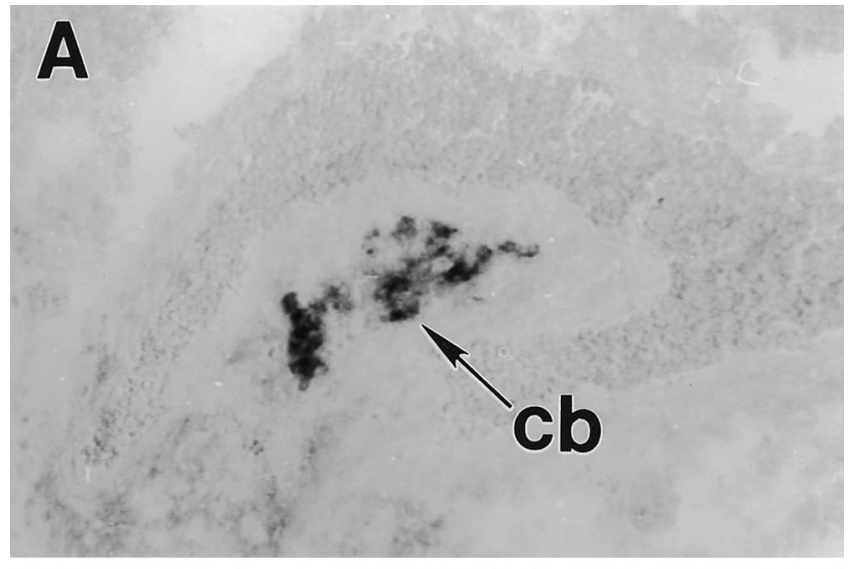

\section{B}
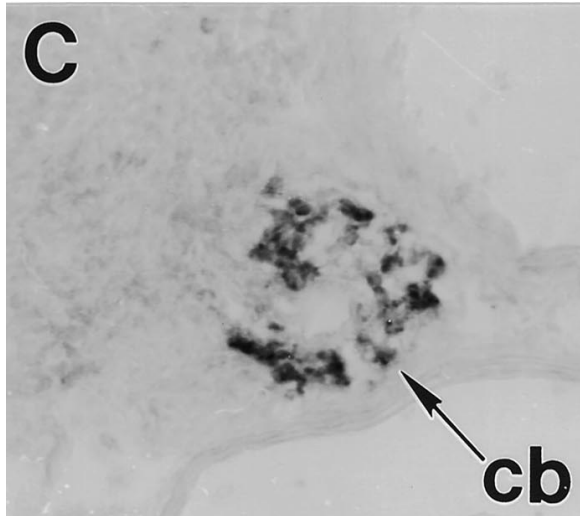

Figure 5. GDNF protein is produced by the fetal and early postnatal mouse carotid body. Photomicrographs of tissue sections through the carotid bifurcation from an E17.5 $(A)$ and newborn $(C)$ mouse show GDNF immunoreactivity within the carotid body at both ages (arrows). Tissues were stained using a GDNF-specific polyclonal antibody (see Materials and Methods). $B$ shows the absence of GDNF immunoreactivity in an adjacent section from the E17.5 mouse in which the primary antibody was omitted during the staining procedure. Scale bar, $50 \mu \mathrm{m}$.

coexpress RET, the signaling component of the GDNF receptor (Durbec et al., 1996; Treanor et al., 1996), by double immunostaining for RET and TH. Of the subpopulation of DA neurons that coexpress $\mathrm{TH}$ and RET, $65 \%$ were lost in the absence of BDNF (Table 3C), 75\% were lost in the absence of GDNF (Table $3 B)$, and virtually all $(98 \%)$ were lost in the absence of both BDNF and GDNF (Table $3 D$; the difference between the single BDNF and GDNF knock-outs was not significant). These data support our finding above that a large subset of DA PG neurons require both BDNF and GDNF for survival in vivo (Table 1). In addition, however, these data indicate that $\sim 30 \%$ of all $\mathrm{TH}^{+}$/ $\mathrm{RET}^{+}$neurons (the difference between the double and single knock-outs) can be supported by either BDNF or GDNF, demonstrating a diversity of trophic requirements of developing PG neurons for BDNF and GDNF in vivo.

\section{Time course of BDNF and GDNF dependence in vivo}

To determine whether BDNF and GDNF are required simultaneously or sequentially, we examined the time course of BDNF and GDNF dependence in the DA population of PG neurons. These studies revealed that, on E14.5, there was already a significant $27 \%$ decrease in DA neuron number in the PG in $b d n f^{-/-}$ mice, compared with wild-type littermates (Fig. 4, top panel). This deficit increased to $39 \%$ by E17.5 and to $\sim 58 \%$ on the day of birth (Table $1 G$ ). DA cell numbers in $g d n f^{-/-}$mice were lower, but not significantly different than wild-type animals on day E14.5 and were significantly lower by E15.5. This deficit increased to $38 \%$ on E17.5 and $42 \%$ at birth (Table $1 F$ ). Thus, loss of DA PG neurons in $b d n f^{-1-}$ mice occurs over a protracted period from E14.5 until birth, whereas most of the cell loss in $g d n f$ $-1-$ mice occurs between E15.5 and E17.5.

\section{GDNF expression in PG target tissues}

We showed previously that BDNF is expressed transiently in NPG target tissues, including the fetal carotid body and cardiac outflow tract, at the onset of sensory innervation, supporting a role for BDNF as a target-derived survival factor for NPG neurons at this stage (Brady et al., 1999). GDNF mRNA has also been detected in NPG target tissues, including the fetal carotid body (Nosrat et al., 1996). In view of our finding that DA PG neurons, the subset of ganglion cells that innervate the carotid body (Katz and Black, 1986), require GDNF, we hypothesized that GDNF, like BDNF, acts as a target-derived survival factor as well. To address this issue we examined GDNF protein expression in the developing carotid body at different developmental ages, using a GDNF-specific antibody. No GDNF immunoreactivity was detectable at the onset of carotid body development on E13.5, or on E14.5. GDNF staining was first detectable on E15.5, increased by E17.5 (Fig. $5 A$ ), and remained strong in newborn animals (Fig. $5 C$ ). The onset of detectable GDNF expression in the carotid body on E15.5 corresponds to the onset of DA cell loss in $g d n f^{-1-}$ mice (Fig. 4, top panel), consistent with the hypothesis that GDNF acts as a target-derived survival factor for PG neurons at this stage.

\section{Physiological role of GDNF-dependent PG neurons}

DA PG neurons play a critical role in control of respiration, and loss of these neurons in newborn $b d n f^{-1-}$ mice is associated with depressed and irregular breathing (Erickson et al., 1996). Therefore, to begin examining the physiological consequences of PG cell loss in $g d n f^{-1-}$ mice, we used plethysmographic techniques to measure breathing frequency in wild-type mice and mice lacking both $g d n f$ alleles, $6-12 \mathrm{hr}$ after birth. During periods of quiet resting breathing, $g d n f^{-1-}$ mice displayed a significant $28 \%$ decrease in breathing frequency and a $43 \%$ increase in the variability of breathing frequency compared with wild-type littermates (Table 4). In addition, we found that newborn GDNF mutants exhibited a 2.4-fold increase in the total number of apneas (defined as periods in which breathing ceased for $\geq 2 \mathrm{sec}$ ), and a 3.8-fold increase in the percentage of recording time spent in apnea, compared with wild-type controls (Table 4). These alterations in normal resting ventilation are qualitatively similar 


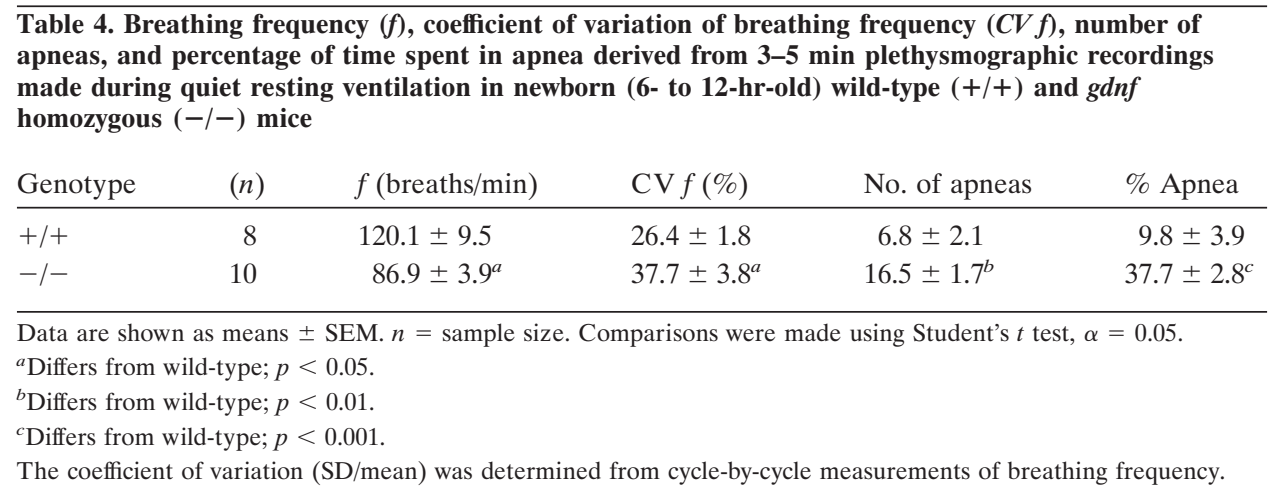

to those observed in the BDNF null mutant (Erickson et al., 1996).

\section{DISCUSSION}

Our findings demonstrate that some primary sensory neurons simultaneously require BDNF and GDNF for survival during fetal development in vivo. Cells that exhibit this dual dependence comprise $\sim 40 \%$ of neurons in the $\mathrm{PG}$, including DA neurons that innervate the carotid body. Moreover, the timing and distribution of GDNF expression in the carotid body are consistent with a role for GDNF as a target-derived survival factor, similar to BDNF (Brady et al., 1999). Finally, our data demonstrate that survival of NG neurons, unlike PG neurons, is unaffected by genetic loss of GDNF, despite the fact that both populations express the GDNF receptor RET and are supported by GDNF in vitro.

Previous studies have shown that multiple populations of peripheral neurons, including the trigeminal, dorsal root, vestibular, cochlear, and superior cervical ganglion, as well as the NPG, require more than one trophic factor over the course of their development for survival in vivo (Reichardt and Farinas, 1997). In many cases, multiple factors act sequentially (Buchman and Davies, 1993; Molliver et al., 1997; Hashino et al., 1999). For example, Buchman and Davies (1993) have shown that trigeminal neurons rely initially on either NT-3 or BDNF for survival, then switch their trophic requirement to NGF. The transition to NGF dependence is correlated with changes in neurotrophin and neurotrophin receptor expression in peripheral target tissues and ganglion cells, respectively (Davies, 1997). Similarly, NPG neurons require NT-3 early in development, during the period of neurogenesis, and many switch their dependence to BDNF at later stages (ElShamy and Ernfors, 1997). In contrast, the present study demonstrates that most of the PG cell loss in $b d n f^{-/-}$and gdnf ${ }^{-/-}$mice occurs at the same time, between E15.5 and E17.5. In view of our finding that the vast majority of GDNF-dependent neurons are a subset of the BDNF-dependent population of ganglion cells, these data indicate that BDNF and GDNF are required simultaneously, rather than sequentially, by these neurons for survival in vivo. In addition, because some further cell loss was observed in bdnf null mice before E14.5 and after E17.5, we cannot rule out the possibility that some cells that initially depend on BDNF switch their dependence to GDNF and vice versa.

The onset of GDNF expression in the mouse carotid body, the target of DA PG neurons, correlates precisely with the onset of DA cell loss in the PG of $g d n f^{-1-}$ mice on E15.5. These data strongly indicate that survival of many DA neurons in the PG depends on the availability of target-derived GDNF. GDNF mRNA has not been detected in either PG neurons themselves
(Nosrat et al., 1996) or in their central target, the brainstem nucleus tractus solitarius (Nosrat et al., 1996; Pochon et al., 1997; Trupp et al., 1997; Golden et al., 1998, 1999), making it unlikely that PG neurons obtain GDNF from sources other than their peripheral targets. In view of the fact that GDNF can be transported to sensory cell bodies from the periphery (Matheson et al., 1997; Leitner et al., 1999), we conclude that GDNF acts as a peripheral target-derived trophic factor for PG neurons, similar to BDNF (Brady et al., 1999).

There are several potential mechanisms that could explain the simultaneous dependence of some PG neurons on BDNF and GDNF. One possibility is that both factors are able to independently support survival, but are present in vivo at concentrations below the threshold for either factor alone to be effective. This possibility is supported by our finding that either BDNF or GDNF alone can support survival of PG neurons in culture and that at subsaturating concentrations, combining the two factors results in an additive increase in survival. Another possibility is that, in vivo, only one of the two factors acts directly to support survival, and the other regulates access or responsiveness to the first (Krieglstein et al., 1998; Schober et al., 1999). GDNF, for example, has been suggested to promote survival of NGFdependent cutaneous afferent neurons by regulating sprouting of the peripheral axons (Fundin et al., 1999). Again, the fact that GDNF can directly support survival of PG neurons in culture argues against this possibility. It is also possible that GDNF stimulates PG neurons to release BDNF, which then acts in an autocrine manner to promote survival (Giehl et al., 1998). We have shown previously that many PG neurons, including DA ganglion cells, contain BDNF in a releasable pool (Brady et al., 1999; Balkowiec and Katz, 2000). However, preliminary studies in our laboratory, using BDNF ELISA, have found no evidence that GDNF stimulates BDNF release from these cells in culture (A. Balkowiec and D. Katz, unpublished observations). Further studies are required to understand how BDNF and GDNF might act in concert to promote survival of sensory neurons. One possibility is that BDNF and GDNF act through common intracellular targets, such as the Ras/Erk pathway (Kaplan and Stephens, 1994; Ohiwa et al., 1997; van-Weering and Bos, 1997, 1998; Trupp et al., 1999), and together activate a threshold response sufficient to support cell survival. It is equally plausible, however, that BDNF and GDNF act independently (Feng et al., 1999).

Approximately $30 \%$ of all $\mathrm{TH}^{+} / \mathrm{RET}^{+}$neurons in the $\mathrm{PG}$ can be supported by either BDNF or GDNF (Table 3), i.e., they are only lost in double $b d n f / g d n f$ null mutants. This finding may be important for understanding the in vivo survival requirements of other populations of DA neurons that are known to respond to 
BDNF and GDNF in vitro. For example, although BDNF and GDNF individually support survival of midbrain DA neurons in vitro (Hyman et al., 1991; Lin et al., 1993), genetic loss of either factor alone has no effect on survival of these neurons in vivo (Ernfors et al., 1994b; Jones et al., 1994; Moore et al., 1996; Sanchez et al., 1996; Granholm et al., 1997). Based on our findings, is possible that BDNF and GDNF can each compensate for the loss of the other to support survival of midbrain DA neurons in single BDNF and GDNF knock-out mice.

Our observation that NG neuron numbers are normal in $g d n f$ mice was unexpected in light of findings that GDNF supports survival of NG neurons in vitro (Henderson et al., 1994; Buj-Bello et al., 1995; Trupp et al., 1995; present study). In situ hybridization studies have revealed the presence of both RET and GFR $\alpha 1$ mRNA in the rat NG (Nosrat et al., 1997), and our immunohistochemical analysis demonstrated that RET protein is present in a large percentage of fetal mouse NG neurons (Fig. 3C). It is possible that any loss of trophic support by GDNF in $g d n f^{-/-}$mice is compensated by other survival factors acting on NG neurons. For example, $90 \%$ of NPG neurons are lost in BDNF/NT-4 double or TrkB null mutant mice (Conover et al., 1995; Erickson et al., 1996), indicating that one or the other of the TrkB ligands supports virtually all NG neurons. On the other hand, GDNF signaling may play other roles in vivo not directly related to supporting NG neuron survival.

We found previously that loss of carotid body afferent neurons in newborn BDNF null mutants is associated with depressed and irregular respiration, indicating that $\mathrm{BDNF}$ is required for development of normal breathing behavior (Erickson et al., 1996). In the present study we observed a similar respiratory phenotype in $g d n f^{-/-}$animals, consistent with our finding that both mutants lack the normal complement of chemoafferent neurons. Recent reports support a role for GDNF dysfunction in at least one developmental abnormality of respiratory control in humans, congenital central hypoventilation syndrome (CCHS; or Ondine's Curse). CCHS is characterized by depressed and irregular breathing and diminished chemical drive, and point mutations in the GDNF and RET genes have each been found in cases of CCHS (Amiel et al., 1998; Sakai et al., 1998). Moreover, newborn mice lacking RET exhibit depressed ventilatory responses to $10 \%$ $\mathrm{CO}_{2}$ (Burton et al., 1997). A point mutation in the BDNF gene has also been discovered in one CCHS patient (S. Bolk and A. Chakravarti, personal communication). Given these human studies, and the fact that BDNF and GDNF are both required for survival of chemoafferent neurons and development of normal breathing behavior in mice, we think it plausible that derangements in either BDNF or GDNF signaling could contribute to the molecular pathogenesis of CCHS by perturbing development of primary sensory neurons in the PG.

\section{REFERENCES}

Abercrombie M (1946) Estimation of nuclear populations from microtome sections. Anat Rec 94:239-247.

Amiel J, Salomon R, Attie T, Pelet A, Trang H, Mokhtari M, Gaultier C, Munnich A, Lyonnet S (1998) Mutations of the RET-GDNF signaling pathway in Ondine's curse. Am J Hum Genet 62:715-717.

Balkowiec A, Katz DM (2000) Activity-dependent release of endogenous brain-derived neurotrophic factor from primary sensory neurons detected by ELISA in situ. J Neurosci 20:7417-7423.

Baloh RH, Enomoto H, Johnson Jr EM, Milbrandt J (2000) The GDNF family ligands and receptors - implications for neural development. Curr Opin Neurobiol 10:103-110.

Brady R, Zaidi SI, Mayer C, Katz DM (1999) BDNF is a target-derived survival factor for arterial baroreceptor and chemoafferent primary sensory neurons. J Neurosci 19:2131-2142.

Buchman VL, Davies AM (1993) Different neurotrophins are expressed and act in a developmental sequence to promote the survival of embryonic sensory neurons. Development 118:989-1001.

Buj-Bello A, Buchman VL, Horton A, Rosenthal A, Davies AM (1995) GDNF is an age-specific survival factor for sensory and autonomic neurons. Neuron 15:821-828.

Burton MD, Kawashima A, Brayer JA, Kazemi H, Shannon DC, Schuchardt A, Costantini F, Pachnis V, Kinane TB (1997) RET protooncogene is important for the development of respiratory $\mathrm{CO}_{2}$ sensitivity. J Auton Nerv Syst 63:137-143.

Cacalano G, Farinas I, Wang LC, Hagler K, Forgie A, Moore M, Armanini M, Phillips H, Ryan AM, Reichardt LF, Hynes M, Davies A, Rosenthal A (1998) GFRalpha1 is an essential receptor component for GDNF in the developing nervous system and kidney. Neuron 21:53-62.

Conner JM, Lauterborn JC, Yan Q, Gall CM, Varon S (1997) Distribution of brain-derived neurotrophic factor $(\mathrm{BDNF})$ protein and mRNA in the normal adult rat CNS: evidence for anterograde axonal transport. J Neurosci 17:2295-2313.

Conover JC, Erickson JT, Katz DM, Bianchi LM, Poueymirou WT, McClain J, Pan L, Helgren M, Ip NY, Boland P, Friedman B, Wiegand S, Vejsada R, Kato AC, DeChiara TM, Yancopoulos GD (1995) Neuronal deficits, not involving motor neurons, in mice lacking BDNF and/or NT4. Nature 375:235-238.

Davies AM (1997) Neurotrophin switching: where does it stand? Curr Opin Neurobiol 7:110-118.

Durbec P, CV, Kilkenny C, Grigoriou M, Wartiowaara K, Suvanto P, Smith D, Ponder B, Costantini F, Saarma M, Sariola H, Pachnis V (1996) GDNF signalling through the Ret receptor tyrosine kinase. Nature 381:789-793.

ElShamy WM, Ernfors P (1997) Brain-derived neurotrophic factor, neurotrophin-3, and neurotrophin-4 complement and cooperate with each other sequentially during visceral neuron development. J Neurosci 17:8667-8675.

Erickson JT, Conover JC, Borday V, Champagnat J, Barbacid M, Yancopoulos G, Katz DM (1996) Mice lacking brain-derived neurotrophic factor exhibit visceral sensory neuron losses distinct from mice lacking NT4 and display a severe developmental deficit in control of breathing. J Neurosci 16:5361-5371.

Ernfors P, Lee K-F, Kucera J, Jaenisch R (1994a) Lack of neurotrophin-3 leads to deficiencies in the peripheral nervous system and loss of limb proprioceptive afferents. Cell 77:503-512.

Ernfors P, Lee K-F, Jaenisch R (1994b) Mice lacking brain-derived neurotrophic factor develop with sensory deficits. Nature 368:147-150.

Farinas I, Jones KR, Backus C, Wang X-Y, Reichardt LF (1994) Severe sensory and sympathetic deficits in mice lacking neurotrophin-3. Nature 369:658-661.

Feng L, Wang CY, Jiang H, Oho C, Dugich DM, Mei L, Lu B (1999) Differential signaling of glial cell line-derived neurotrophic factor and brain-derived neurotrophic factor in cultured ventral mesencephalic neurons. Neuroscience 93:265-273.

Fundin BT, Mikaels A, Westphal H, Ernfors P (1999) A rapid and dynamic regulation of GDNF-family ligands and receptors correlate with the developmental dependency of cutaneous sensory innervation. Development 126:2597-2610.

Giehl KM, Schutte A, Mestres P, Yan Q (1998) The survival-promoting effect of glial cell line-derived neurotrophic factor on axotomized corticospinal neurons in vivo is mediated by an endogenous brainderived neurotrophic factor mechanism. J Neurosci 18:7351-7360.

Golden JP, Baloh RH, Kotzbauer PT, Lampe PA, Osborne PA, Milbrandt J, Johnson Jr EM (1998) Expression of neurturin, GDNF, and their receptors in the adult mouse CNS. J Comp Neurol 398:139-150.

Golden JP, Demaro JA, Osborne PA, Milbrandt J, Johnson Jr EM (1999) Expression of neurturin, GDNF, and GDNF family-receptor mRNA in the developing and mature mouse. Exp Neurol 158:504-528.

Granholm AC, Srivastava N, Mott JL, Henry S, Henry M, Westphal H, Pichel JG, Shen L, Hoffer BJ (1997) Morphological alterations in the peripheral and central nervous systems of mice lacking glial cell linederived neurotrophic factor (GDNF): immunohistochemical studies. J Neurosci 17:1168-1178.

Hashino E, Dolnick RY, Cohan CS (1999) Developing vestibular ganglion neurons switch trophic sensitivity from BDNF to GDNF after target innervation. J Neurobiol 38:414-427.

Henderson CE, Phillips HS, Pollock RA, Davies AM, Lemeulle C, Armanini M, Simmons L, Moffet B, Vandlen RA, Simpson LC (1994) GDNF: a potent survival factor for motoneurons present in peripheral nerve and muscle. Science 266:1062-1064.

Hertzberg T, Fan G, Finley JCW, Erickson JT, Katz DM (1994) BDNF supports mammalian chemoafferent neurons in vitro and following peripheral target removal in vivo. Dev Biol 166:801-811.

Hyman C, Hofer M, Barde YA, Juhasz M, Yancopoulos GD, Squinto SP, Lindsay RM (1991) BDNF is a neurotrophic factor for dopaminergic neurons of the substantia nigra. Nature 350:230-232.

Jones KR, Farinas I, Backus C, Reichardt LF (1994) Targeted disruption of the BDNF gene perturbs brain and sensory neuron development but not motor neuron development. Cell 76:989-999. 
Kaplan DR, Stephens RM (1994) Neurotrophin signal transduction by the Trk receptor. J Neurobiol 25:1404-1417.

Katz DM, Black IB (1986) Expression and regulation of catecholaminergic traits in primary sensory neurons: relationship to target innervation in vivo. J Neurosci 6:983-989.

Krieglstein K, Henheik P, Farkas L, Jaszai J, Galter D, Krohn K, Unsicker K (1998) Glial cell line-derived neurotrophic factor requires transforming growth factor-beta for exerting its full neurotrophic potential on peripheral and CNS neurons. J Neurosci 18:9822-9834.

Leitner ML, Molliver DC, Osborne PA, Vejsada R, Golden JP, Lampe PA, Kato AC, Milbrandt J, Johnson Jr EM (1999) Analysis of the retrograde transport of glial cell line-derived neurotrophic factor (GDNF), neurturin, and persephin suggests that in vivo signaling for the GDNF family is GFR $\alpha$ coreceptor-specific. J Neurosci 19:9322-9331.

Lin LF, Doherty DH, Lile JD, Bektesh S, Collins F (1993) GDNF: a glial cell line-derived neurotrophic factor for midbrain dopaminergic neurons. Science 260:1130-1132.

Liu X, Ernfors P, Wu H, Jaenisch R (1995) Sensory but not motor neuron deficits in mice lacking NT4 and BDNF. Nature 375:238-241.

Mains RE, Patterson PH (1973) Primary cultures of dissociated sympathetic neurons. I. Establishment of long-term growth in culture and studies of differentiated properties. J Cell Biol 59:329-345.

Matheson CR, Carnahan J, Urich JL, Bocangel D, Zhang TJ, Yan Q (1997) Glial cell line-derived neurotrophic factor (GDNF) is a neurotrophic factor for sensory neurons: comparison with the effects of the neurotrophins. J Neurobiol 32:22-32.

Molliver DC, Wright DE, Leitner ML, Parsadanian AS, Doster K, Wen D, Yan Q, Snider WD (1997) IB4-binding DRG neurons switch from NGF to GDNF dependence in early postnatal life. Neuron 19:849-861.

Moore MW, Klein RD, Farinas I, Sauer H, Armanini M, Phillips H, Reichardt LF, Ryan AM, Carver-Moore K, Rosenthal A (1996) Renal and neuronal abnormalities in mice lacking GDNF. Nature 382:76-79.

Mortola JP (1984) Breathing patterns in newborns. J Appl Physiol 56:1533-1540.

Mortola JP, Noworaj A (1983) Two-sidearm tracheal cannula for respiratory airflow measurements in small animals. J Appl Physiol 55:250-253.

Nosrat CA, Tomac A, Lindqvist E, Lindskog S, Humpel C, Stromberg I, Ebendal T, Hoffer BJ, Olson L (1996) Cellular expression of GDNF mRNA suggests multiple functions inside and outside the nervous system. Cell Tissue Res 286:191-207.

Nosrat CA, Tomac A, Hoffer BJ, Olson L (1997) Cellular and developmental patterns of expression of Ret and glial cell line-derived neurotrophic factor receptor alpha mRNAs. Exp Brain Res 115:410-422.

Ohiwa M, Murakami H, Iwashita T, Asai N, Iwata Y, Imai T, Funahashi H, Takagi H, Takahashi M (1997) Characterization of Ret-Shc-Grb2 complex induced by GDNF, MEN 2A, and MEN 2B mutations. Biochem Biophys Res Commun 237:747-751.

Pichel JG, Shen L, Sheng HZ, Granholm AC, Drago J, Grinberg A, Lee
EJ, Huang SP, Saarma M, Hoffer BJ, Sariola H, Westphal H (1996) Defects in enteric innervation and kidney development in mice lacking GDNF. Nature 382:73-76.

Pochon NA, Menoud A, Tseng JL, Zurn AD, Aebischer P (1997) Neuronal GDNF expression in the adult rat nervous system identified by in situ hybridization. Eur J Neurosci 9:463-471.

Reichardt LF, Farinas I (1997) Neurotrophic factors and their receptors. Roles in neuronal development and function. In: Molecular and cellular approaches to neural development (Cowan WM, Jessell TM, Zipursky SL, eds), pp 220-263. New York: Oxford UP.

Rosenthal A (1999) The GDNF protein family: gene ablation studies reveal what they really do and how. Neuron 22:201-203.

Sakai T, Wakizaka A, Matsuda H, Nirasawa Y, Itoh Y (1998) Point mutation in exon 12 of the receptor tyrosine kinase proto-oncogene RET in Ondine-Hirschsprung syndrome. Pediatrics 101:924-926.

Sanchez MP, Silos-Santiago I, Frisen J, He B, Lira SA, Barbacid M (1996) Renal agenesis and the absence of enteric neurons in mice lacking GDNF. Nature 382:70-73

Schober A, Hertel R, Arumae U, Farkas L, Jaszai J, Krieglstein K, Saarma M, Unsicker K (1999) Glial cell line-derived neurotrophic factor rescues target-deprived sympathetic spinal cord neurons but requires transforming growth factor-beta as cofactor in vivo. J Neurosci 19:2008-2015.

Theiler K (1972) The house mouse. Development and normal stages from fertilization to 4 weeks of age. New York: Springer.

Treanor JJ, Goodman L, de SF, Stone DM, Poulsen KT, Beck CD, Gray C, Armanini MP, Pollock RA, Hefti F, Phillips HS, Goddard A, Moore MW, Buj-Bello A, Davies AM, Asai N, Takahashi M, Vandlen R, Henderson CE, Rosenthal A (1996) Characterization of a multicomponent receptor for GDNF. Nature 382:80-83.

Trupp M, Ryden M, Jornvall H, Funakoshi H, Timmusk T, Arenas E, Ibanez CF (1995) Peripheral expression and biological activities of GDNF, a new neurotrophic factor for avian and mammalian peripheral neurons. J Cell Biol 130:137-148.

Trupp M, Belluardo N, Funakoshi H, Ibanez CF (1997) Complementary and overlapping expression of glial cell line-derived neurotrophic factor (GDNF), c-ret proto-oncogene, and GDNF receptor-alpha indicates multiple mechanisms of trophic actions in the adult rat CNS. J Neurosci 17:3554-3567.

Trupp M, Scott R, Whittemore SR, Ibanez CF (1999) Ret-dependent and -independent mechanisms of glial cell line-derived neurotrophic factor signaling in neuronal cells. J Biol Chem 274:20885-20894.

Unsicker K, Suter-Crazzolara C, Krieglstein K (1998) Neurotrophic roles of GDNF and related factors. In: Handbook of experimental pharmacology (Hefti F, ed), pp 189-224. Berlin: Springer.

van-Weering DH, Bos JL (1997) Glial cell line-derived neurotrophic factor induces Ret-mediated lamellipodia formation. J Biol Chem 272:249-254

van-Weering DH, Bos JL (1998) Signal transduction by the receptor tyrosine kinase Ret. Recent Results Cancer Res 154:271-281. 